\title{
Alexandre Dumas, Un Gil Blas en Californie
}

\section{Michel Arrous}

\section{(2) OpenEdition}

\section{Journals}

\section{Édition électronique}

URL : http://journals.openedition.org/studifrancesi/7640

DOI : 10.4000/studifrancesi.7640

ISSN : 2427-5856

\section{Éditeur}

Rosenberg \& Sellier

\section{Édition imprimée}

Date de publication : 1 décembre 2009

Pagination : 649-650

ISSN : 0039-2944

\section{Référence électronique}

Michel Arrous, «Alexandre Dumas, Un Gil Blas en Californie », Studi Francesi [En ligne], 159 (LIII | III) |

2009, mis en ligne le 30 novembre 2015, consulté le 09 janvier 2021. URL : http://

journals.openedition.org/studifrancesi/7640; DOI : https://doi.org/10.4000/studifrancesi.7640

Ce document a été généré automatiquement le 9 janvier 2021.

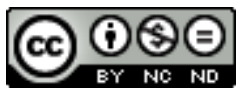

Studi Francesi è distribuita con Licenza Creative Commons Attribuzione - Non commerciale - Non opere derivate 4.0 Internazionale. 


\title{
Alexandre Dumas, Un Gil Blas en Californie
}

\author{
Michel Arrous
}

\section{RÉFÉRENCE}

ALEXANDRE DUMAS, Un Gil Blas en Californie, illustrations de C. Gaillard, préface de J. GLENISSON, Saulx-les-Chartreux, Éditions Pollagoras, 2007, pp. 158.

1 Après Un Pays inconnu et El Salteador, la collection «Tout Dumas illustré» s'enrichit d'un troisième titre, Un Gil Blas en Californie, publié d'abord dans "Le Siècle", du 15 avril au 2 mai 1852, sous le titre Californie. Un an sur les bords du San Joachim et du Sacramento, puis en volume la même année et en 1861 et, une dernière fois, en 1897. Ajoutons que l'œuvre a connu plusieurs traductions, notamment aux États-Unis. Cette «curieuse histoire» - selon l'expression de Dumas - n'est pas dépourvue d'intérêt, mais les tribulations de ce très lointain parent du héros de Le Sage, tour à tour chercheur d'or, chasseur, garçon de restaurant et marchand de vin à San Francisco, valent moins sans doute que le plaisant récit des circonstances dans lesquelles l' «historien signataire» rôle que Dumas modestement s'attribue - fit sa rencontre. À l'en croire, ce fut un soir de juillet 1851, où il trouva refuge dans la chambre de mademoiselle Rachel de l'hôtellerie Leduc, à Montmorency, qu'il fit un voyage en Californie sans y être jamais allé. C'est le journal de ce voyage qu'il aurait très peu revu, très peu corrigé et pas du tout augmenté, que Dumas propose à son éditeur dans une lettre-préface qui, à elle seule, justifierait la reprise de ce récit mineur dont la trame appartient sans doute au journaliste et romancier Bénédict-Henry Revoil (1816-1882), fils du peintre d'histoire et frère du célèbre architecte, qui se fit un nom dans les récits de Peaux-Rouges, les histoires de chasse et les romans d'aventures géographiques. De ce collaborateur très occasionnel auquel Dumas offrit d'ailleurs quelques textes, on retiendra une formule bien frappée qui ne l'honore guère tant il lui arriva de gauchir la vérité: «Il y a quelque chose de plus invraisemblable que le roman, c'est la réalité» (1881). À quelques 
coquilles près, un index fantaisiste et des illustrations inégales, cette réédition est une heureuse idée. 